\title{
PENGEMBANGAN PROSES BISNIS DAN RANCANGAN APLIKASI SISTEM INFORMASI PENERIMAAN DAN PENILAIAN PESERTA CO - ASS PADA RSUD
}

\author{
Yanti; Yunita Fransisca; Jacklyn Suwargo \\ Computerized Accounting Department, School of Information Systems, Binus University \\ Jl. K.H. Syahdan No. 9, Palmerah, Jakarta Barat 11480 \\ yanti@binus.edu
}

\begin{abstract}
This study aims to is to explore the admission process and assessment of participant Co - Assistant doctor on a regional hospital which is still performed manually, to identify problems encountered and required information in the development of Information Systems of Participants Acceptance and Assessment of Co Assistant doctor, and design the information System . Methods used are literature study, data collection (observation and interviews), analysis, and design. This study results in a computerized information systems of acceptance and assessment of Co - Ass participant to improve the quality of service from the Human Resources division. Creating the required reports assists the Head of HR to determine the performance of Co - Ass. In addition, the design of information systems reduces the possibility of data losses and documents recording errors made by the Executive Training Unit, and assist the hospital management in confirming the existing organizational structure and its duty of each division to provide document creation system and authorization by the external parties.
\end{abstract}

Keywords: information system, recruitment, assessment, Co - Ass

\begin{abstract}
ABSTRAK
Penelitian ini bertujuan untuk mengetahui proses penerimaan dan penilaian peserta Co - Ass pada RSUD yang masih dilakukan secara manual, mengidentifikasi masalah yang terjadi serta informasi apa saja yang dibutuhkan dalam Pengembangan Sistem Informasi Penerimaan dan Penilaian Peserta Co - Ass pada RSUD, dan merancang Pengembangan Sistem Informasi Penerimaan dan Penilaian Peserta Co- Ass pada RSUD. Metode penelitian yang digunakan adalah studi kepustakaan, pengumpulan data (observasi dan wawancara), analisis, dan perancangan. Hasil yang dicapai adalah sistem informasi penerimaan dan penilaian peserta Co - Ass yang terkomputerisasi sehingga dapat membantu pihak Diklat RSUD dalam bekerja serta meningkatkan mutu dan kualitas pelayanan dari divisi Sumber Daya Manusia. Dibuatnya laporan-laporan yang dibutuhkan dapat membantu pihak Kepala Bagian SDM dalam mengetahui kinerja kegiatan Co - Ass. Selain itu, rancangan Sistem Informasi ini dapat mengurangi kemungkinan kehilangan data dan kesalahan pencatatan dokumen yang dilakukan oleh bagian Satuan Pelaksana Diklat, dan membantu Rumah Sakit dalam menegaskan struktur organisasi yang telah ada beserta tugas masing-masing divisi dengan memberikan sistem pembuatan dokumen dan otorisasi oleh pihak yang berbeda.
\end{abstract}

Kata kunci: sistem informasi, penerimaan, penilaian, Co - Ass 


\section{PENDAHULUAN}

SDM merupakan salah satu elemen organisasi yang difungsikan sebagai tenaga kerja pengelolaan dan penggerak roda bisnis organisasi, untuk mewujudkan visi, misi, dan tujuannya. Peran SDM dalam sebuah organisasi begitu penting dan sangat menentukan, maka harus dikelola secara sistematis, terencana, dan terpola agar tujuan organisasi di saat sekarang dan yang akan datang dapat dicapai secara optimal. Langkah tersebut akan mengubah kompetensi personil meliputi pengetahuan, kemampuan, keterampilan, dan sikap. (Sakam dan Surendro, 2007). Menurut Noerlina (2008), Sistem Informasi Sumber Daya Manusia telah menjadi suatu acuan untuk mendapatkan jaminan dari tersedianya tenaga kerja yang tepat untuk menduduki suatu jabatan dan pekerjaan yang tepat dan waktu yang tepat bagi organisasi untuk mewujudkan tujuan dan sasaran perusahaan. Di dalam dunia bisnis yang semakin berkembang ini, perusahaan akan sangat membutuhkan kinerja dari Sumber Daya Manusia yang berkualitas tinggi. Untuk itu, perusahaan harus melakukan suatu pelatihan yang dapat membantu meningkatkan kualitas dari Sumber Daya Manusianya. Dengan begitu, Sistem Informasi dianggap penting untuk mendukung kegiatan tersebut.

Rumah sakit sebagai salah satu badan usaha yang bergerak di bidang pelayanan kesehatan berfokus pada ketepatan dan kemampuan praktik yang tinggi pun harus memperhatikan kualitas sumber daya manusia. Pelatihan yang tepat di dalam pengembangan kompetensi sumber daya manusia menjadi salah satu proses yang harus dijalani sebagai jaminan kepada masyarakat bahwa sumber daya manusia yang dihasilkan memiliki kompetensi yang dapat diandalkan. Salah satu divisi di RSUD yang mengolah data sumber daya manusia adalah divisi Sumber Daya Manusia bagian Satuan Pelaksana Diklat (Pendidikan dan Pelatihan). Sistem yang diterapkan dalam RSUD pada umumnya masih semi manual karena untuk pengolahan data, penggunaannya masih bersifat manual di beberapa divisi.

Pada umumnya RSUD memiliki fungsi sebagai berikut: (1) penyusunan dan pelaksanaan rencana kerja dan anggaran; (2) penyelenggaraan pelayanan medis; (3) penyelenggaraan pelayanan penunjang medis; (4) penyelenggaraan pelayanan asuhan keperawatan; (5) penyelenggaraan pelayanan rujukan dan ambulans; (6) penyelenggaraan peningkatan mutu pelayanan; (7) penyelenggaraan urusan rekam medis; (8) penyelenggaraan pelayanan kegawatdaruratan; (9) penyelenggaraan kesehatan dan keselamatan kerja; (10) penyelenggaraan kesehatan lingkungan rumah sakit; (11)penyelenggaraan pelayanan pemulasaran rumah sakit; (12) penyelenggaraan keselamatan pasien; (13) fasilitasi penyelenggaraan pendidikan dan pelatihan tenaga kesehatan; (14) fasilitasi penelitian dan pengembangan pelayanan kesehatan; (15) pelaksanaan kerjasama dengan pihak ketiga dalam rangka meningkatkan pelayanan kesehatan perorangan; (16) penyusunan dan pelaksanaan standar pelayanan; (17) penyusunan dan pelaksanaan standar operasional prosedur pelayanan; (18) penyediaan, penatausahaan, penggunaan, pemeliharaan, dan perawatan prasarana dan sarana kerja RSUD; (19) pemberian dukungan teknis kepada masyarakat dan perangkat daerah; (20) pengelolaan kepegawaian, keuangan dan persediaan; (21) pengelolaan ketatausahaan RSUD; (22) pelaporan dan pertanggungjawaban pelaksanaan tugas dan fungsi. Dilihat dari kegiatan usahanya, dibutuhkan informasi yang cepat, tepat serta akurat bagi sebuah Rumah Sakit. Oleh karena itu, tulisan ini akan membahas bisnis proses dan pengembangan sistem informasi penerimaan dan penilaian peserta Co Ass pada RSUD.

\section{METODE}

Metode penelitian yang dilakukan adalah dengan pengumpulan data mengenai bisnis proses yang terjadi di RSUD. Dari hasi analisis bisnis proses tersebut kemudian disusun rancangan bisnis proses baru yang dapat memberikan penyelesaian atas masalah yang terjadi. 
Penelitian difokuskan pada ruang lingkup penerimaan permohonan kerja sama dari Institusi, penerimaan permohonan Co - Ass, penunjukan pembimbing yang dilakukan oleh Unit Kerja, memberikan penilaian terhadap peserta Co - Ass yang dilakukan oleh Pembimbing, penerimaan pengajuan ujian ulang dari Institusi, pencatatan jumlah absensi, pembuatan surat keterangan yang terkait, pembuatan dan penerimaan laporan yang terkait serta pembuatan transkrip nilai peserta Co Ass.

\section{HASIL DAN PEMBAHASAN}

\section{Proses Bisnis yang berjalan}

Berikut adalah proses bisnis yang berjalan pada sebuah RSUD (Tabel1).

Tabel 1 Event Table Proses Berjalan pada RSUD

\begin{tabular}{|c|c|c|c|}
\hline Event & $\begin{array}{c}\text { Internal Agent } \\
\text { Assuming } \\
\text { Responsibilities }\end{array}$ & Start When & Activities \\
\hline $\begin{array}{l}\text { 1. Menerima } \\
\text { permohonan } \\
\text { kerja sama }\end{array}$ & $\begin{array}{l}\text { Satuan Pelaksana } \\
\text { Diklat }\end{array}$ & $\begin{array}{l}\text { Institusi } \\
\text { memberikan Surat } \\
\text { Permohonan Kerja } \\
\text { Sama sebanyak satu } \\
\text { rangkap }\end{array}$ & $\begin{array}{l}\text { Menerima Surat Permohonan Kerja Sama sebanyak satu } \\
\text { rangkap, memberikan Surat Permohonan Kerja Sama } \\
\text { sebanyak satu rangkap kepada Direktur }\end{array}$ \\
\hline $\begin{array}{l}\text { 2. } \\
\text { Mendisposisi- } \\
\text { kan permohonan } \\
\text { kerja sama }\end{array}$ & Direktur & $\begin{array}{l}\text { Menerima Surat } \\
\text { Permohonan Kerja } \\
\text { Sama sebanyak satu } \\
\text { rangkap dari Satuan } \\
\text { Pelaksana Diklat } \\
\end{array}$ & $\begin{array}{l}\text { Membuat Lembar Disposisi sebanyak satu rangkap, } \\
\text { mengotorisasi Surat Permohonan Kerja Sama dan } \\
\text { Lembar Disposisi, memberikan Surat Permohonan } \\
\text { Kerja Sama dan Lembar Disposisi kepada Unit Kerja }\end{array}$ \\
\hline $\begin{array}{l}\text { 3. Mengunjungi } \\
\text { Institusi }\end{array}$ & Unit Kerja & $\begin{array}{l}\text { Menerima Surat } \\
\text { Permohonan Kerja } \\
\text { Sama dan Lembar } \\
\text { Disposisi dari } \\
\text { Direktur }\end{array}$ & $\begin{array}{l}\text { Membuat Check List Visitasi sebanyak satu rangkap, } \\
\text { melapor kepada Satuan Pelaksana Diklat untuk } \\
\text { melakukan pengunjungan serta meminta contoh IKS } \\
\text { (Ikatan Kerja Sama), mengunjungi Institusi, mengisi } \\
\text { Check List Visitasi, memberikan contoh IKS kepada } \\
\text { Institusi, memberikan Check List Visitasi yang telah } \\
\text { diisi kepada Satuan Pelaksana Diklat }\end{array}$ \\
\hline $\begin{array}{l}\text { 4. Menerima Check } \\
\text { List Visitasi dan } \\
\text { IKS }\end{array}$ & $\begin{array}{l}\text { Satuan Pelaksana } \\
\text { Diklat }\end{array}$ & $\begin{array}{l}\text { Menerima Check } \\
\text { List Visitasi yang } \\
\text { telah diisi oleh Unit } \\
\text { Kerja }\end{array}$ & $\begin{array}{l}\text { Memeriksa Check List Visitasi yang telah diisi, } \\
\text { mengarsip Check List Visitasi yang telah diisi, } \\
\text { menerima IKS sebanyak dua rangkap dari Institusi, } \\
\text { memeriksa IKS, mengotorisasi IKS, menyerahkan IKS } \\
\text { kepada Kepala Bagian SDM }\end{array}$ \\
\hline
\end{tabular}

\begin{tabular}{|c|c|c|c|c|}
\hline 5. & $\begin{array}{l}\text { Mengotorisasi } \\
\text { IKS }\end{array}$ & $\begin{array}{l}\text { Kepala Bagian } \\
\text { SDM }\end{array}$ & $\begin{array}{l}\text { Menerima IKS } \\
\text { yang telah } \\
\text { diotorisasi oleh } \\
\text { Satuan Pelaksana } \\
\text { Diklat }\end{array}$ & $\begin{array}{l}\text { Memeriksa IKS yang telah diotorisasi oleh Satuan } \\
\text { Pelaksana Diklat, mengotorisasi IKS, memberikan IKS } \\
\text { yang telah diotorisasi kepada Direktur }\end{array}$ \\
\hline 6. & $\begin{array}{l}\text { Mengesahkan } \\
\text { IKS }\end{array}$ & Direktur & $\begin{array}{l}\text { Menerima IKS } \\
\text { yang telah } \\
\text { diotorisasi oleh } \\
\text { Satuan Pelaksana } \\
\text { Diklat dan Kepala } \\
\text { Bagian SDM }\end{array}$ & $\begin{array}{l}\text { Menandatangani IKS, menyerahkan IKS yang telah } \\
\text { ditandatangani kepada Satuan Pelaksana Diklat }\end{array}$ \\
\hline
\end{tabular}




\begin{tabular}{|c|c|c|c|}
\hline Event & $\begin{array}{c}\text { Internal Agent } \\
\text { Assuming } \\
\text { Responsibilities }\end{array}$ & Start When & Activities \\
\hline $\begin{array}{l}\text { 7. Menerima } \\
\text { permohonan } \mathrm{Co} \text { - } \\
\text { Ass }\end{array}$ & $\begin{array}{l}\text { Satuan Pelaksana } \\
\text { Diklat }\end{array}$ & $\begin{array}{l}\text { Menerima IKS } \\
\text { yang telah disahkan }\end{array}$ & $\begin{array}{l}\text { Mengarsip IKS rangkap satu, mengirimkan IKS } \\
\text { rangkap dua kepada Institusi, menerima Surat } \\
\text { Permohonan Co - Ass sebanyak tiga rangkap dari } \\
\text { Institusi beserta pas foto dan fotocopy KTP peserta, } \\
\text { memberikan Surat Permohonan Co - Ass rangkap satu } \\
\text { kepada Direktur, memberikan SuratPermohonan Co - } \\
\text { Ass rangkap dua kepada Unit Kerja, mengarsip Surat } \\
\text { Permohonan Co - Ass rangkap tiga, memberitahu } \\
\text { Institusi untuk pembuatan Surat Konfirmasi sebanyak } \\
\text { dua rangkap, membuat Name Tag peserta, membuat } \\
\text { daftar absensi }\end{array}$ \\
\hline
\end{tabular}

\begin{tabular}{|c|c|c|c|}
\hline 8. & $\begin{array}{l}\text { Menerima Surat } \\
\text { Konfirmasi }\end{array}$ & $\begin{array}{l}\text { Satuan Pelaksana } \\
\text { Diklat }\end{array}$ & $\begin{array}{l}\text { Menerima Surat } \\
\text { Konfirmasi } \\
\text { sebanyak dua } \\
\text { rangkap dari } \\
\text { peserta Co - Ass }\end{array}$ \\
\hline
\end{tabular}
Mengotorisasi Surat Konfirmasi, membuat Surat
Pengantar sebanyak dua rangkap, memberikan Name
Tag kepada peserta, memberikan Surat Konfirmasi
rangkap satu dan Surat Pengantar rangkap satu kepada
peserta untuk diberikan kepada Unit Kerja, mengarsip
Surat Konfirmasi rangkap dua dan Surat Pengantar
rangkap dua, memberikan Daftar Absensi kepada
peserta untuk diisi, menyimpan Daftar Absensi yang
telah diisi oleh peserta, memberikan Daftar Absensi
yang telah diisi selama satu minggu oleh peserta kepada
Kepala Bagian SDM

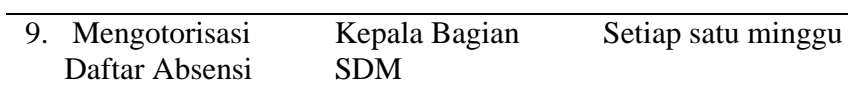

Menerima Daftar Absensi yang telah diisi selama satu minggu oleh peserta, mengotorisasi Daftar Absensi, menyerahkan kembali Daftar Absensi yang telah diotorisasi kepada Satuan Pelaksana Diklat untuk diarsip

\begin{tabular}{|c|c|c|}
\hline $\begin{array}{l}\text { 10. } \\
\text { Memberikan } \\
\text { penilaian }\end{array}$ & Pembimbing & $\begin{array}{l}\text { Kegiatan Co - Ass } \\
\text { dilaksanakan }\end{array}$ \\
\hline
\end{tabular}

Memberikan nilai pada tes awal, memberikan nilai pada kuis, memberikan nilai pada sikap, memberikan nilai pada ujian tertulis, memberikan nilai pada ujian praktek, membuat Laporan Nilai, menyerahkan Laporan Nilai kepada Satuan Pelaksana Diklat

\begin{tabular}{clll}
\hline $\begin{array}{c}\text { 11. Membuat } \\
\text { Transkrip Nilai }\end{array}$ & $\begin{array}{l}\text { Satuan Pelaksana } \\
\text { Diklat }\end{array}$ & $\begin{array}{l}\text { Kegiatan Co - Ass } \\
\text { telah berakhir }\end{array}$ & $\begin{array}{l}\text { Membuat Transkrip Nilai, mengotorisasi Transkrip } \\
\text { Nilai, mengirimkan Transkrip Nilai kepada pihak } \\
\text { Institusi }\end{array}$ \\
\hline $\begin{array}{c}\text { 12. Menerima } \\
\text { pengajuan ujian } \\
\text { ulang }\end{array}$ & $\begin{array}{l}\text { Satuan Pelaksana } \\
\text { Diklat }\end{array}$ & $\begin{array}{l}\text { Menerima Surat } \\
\text { Pengajuan Ujian } \\
\text { Ulang sebanyak } \\
\text { dua rangkap dari } \\
\text { Institusi }\end{array}$ & $\begin{array}{l}\text { Memberikan Surat Pengajuan Ujian Ulang rangkap satu } \\
\text { kepada Unit Kerja untuk mengkonfirmasikan kepada } \\
\text { Pembimbing, mengarsip Surat Pengajuan Ujian Ulang } \\
\text { rangkap dua, }\end{array}$ \\
\hline $\begin{array}{c}\text { 13. Memberikan } \\
\text { penilaian ujian } \\
\text { ulang }\end{array}$ & Pembimbing & $\begin{array}{l}\text { Kegiatan ujian } \\
\text { ulang telah berakhir }\end{array}$ & $\begin{array}{l}\text { Memberikan nilai pada ujian ulang, membuat Laporan } \\
\text { Nilai Ujian Ulang, menyerahkan Laporan Nilai Ujian } \\
\text { Ulang kepada Satuan Pelaksana Diklat }\end{array}$ \\
& & & \\
\hline $\begin{array}{c}\text { 14. Membuat } \\
\text { Transkrip Nilai }\end{array}$ & Satuan Pelaksana & Menerima Laporan \\
Diklan Ulang & & Nilai Ujian Ulang & $\begin{array}{l}\text { Membuat Transkrip Nilai Ujian Ulang, mengotorisasi } \\
\text { Transkrip Nilai Ujian Ulang, mengirimkan Transkrip } \\
\text { Nilai Ujian Ulang kepada pihak Institusi }\end{array}$ \\
& & &
\end{tabular}

Dokumen yang digunakan dan dihasilkan pada sistem berjalan antara lain: (1) lembar disposisi, yaitu formulir yang dibuat oleh Direktur sebagai instruksi menanggapi surat permohonan yang diajukan. Lembar disposisi diberikan kepada Koordinator Satuan Pelaksana Diklat untuk diserahkan kepada unit kerja; (2) check list visitasi, yaitu formulir yang dibuat dan diisi oleh unit kerja 
ketika mengunjungi institusi asal peserta untuk diarsip; (3) tanda pengenal (name tag), yang dibuat oleh Koordinator Satuan Pelaksana Diklat yang harus selalu dibawa oleh peserta selama Co - Ass berlangsung; (4) surat pengantar mengenai izin melakukan kegiatan Co - Ass, dibuat oleh Staff Satuan Pelaksana Diklat yang kemudian diberikan kepada peserta untuk diserahkan kepada unit kerja yang dituju; (5) daftar absensi, dibuat oleh Staff Satuan Pelaksana Diklat yang akan diserahkan kepada Kepala Bagian SDM untuk diotorisasi sebagai bukti kehadiran peserta Co - Ass; (6) laporan nilai yang dibuat oleh pembimbing tentang data peserta Co - Ass di unit nya, ditujukan kepada Satuan Pelaksana Diklat; (7) transkrip nilai yang dibuat berdasarkan laporan daftar peserta, diserahkan oleh pembimbing kepada Satuan Pelaksana Diklat yang akan dikirimkan kepada Institusi asal peserta.

\section{Permasalah yang Dihadapi}

Dari hasil analisis lapangan ditemukan beberapa masalah yaitu: (1) masih kurangnya dokumen pendukung untuk pengolahan data seperti Form Penunjukan Pembimbing dan Form Ujian Ulang; (2) proses kerja yang masih dilakukan manual sering menyebabkan terjadinya kehilangan dokumen seperti Surat Permohonan Kerja Sama. Selain itu informasi yang dibutuhkan seperti Laporan Penerimaan Calon Peserta Co - Ass, Laporan Penerimaan Peserta Co - Ass, Laporan Peserta Mengulang, Laporan Absensi, Laporan Penilaian Peserta, Laporan Nilai Ujian Ulang, Laporan Penunjukan Pembimbing, Laporan Total Peserta, Laporan Minat Institusi, Laporan Persentase Kelulusan Peserta tidak dapat dihasilkan karena data yang tersebar dalam bentuk dokumen kertas dan jikapun ingin disusun akan membutuhkan waktu di dalam pengerjaannya.

\section{Rancangan Proses Bisnis yang Baru} 2 berikut:

Untuk mengatasi masalah di atas, disusun bisnis proses baru sesuai yang diuraikan pada Tabel

Tabel 2 Event Table yang dikembangkan untuk RSUD

\begin{tabular}{|c|c|c|c|}
\hline Event & $\begin{array}{l}\text { Internal Agent } \\
\text { Assuming } \\
\text { Responsibilities }\end{array}$ & Start When & Activities \\
\hline $\begin{array}{l}\text { 1. Menerima permohonan } \\
\text { kerja sama }\end{array}$ & $\begin{array}{l}\text { Satuan Pelaksana } \\
\text { Diklat }\end{array}$ & $\begin{array}{l}\text { Institusi memberikan } \\
\text { Surat Permohonan } \\
\text { Kerja Sama sebanyak } \\
\text { satu rangkap }\end{array}$ & $\begin{array}{l}\text { Menerima Surat Permohonan Kerja Sama } \\
\text { sebanyak satu rangkap, memeriksa Surat } \\
\text { Permohonan Kerja Sama, mengotorisasi Surat } \\
\text { Permohonan Kerja Sama, memberikan Surat } \\
\text { Permohonan Kerja Sama sebanyak satu } \\
\text { rangkap kepada Direktur }\end{array}$ \\
\hline $\begin{array}{l}\text { 2. Menyetujui } \\
\text { permohonan kerja } \\
\text { sama }\end{array}$ & Direktur & $\begin{array}{l}\text { Menerima Surat } \\
\text { Permohonan Kerja } \\
\text { Sama sebanyak satu } \\
\text { rangkap dari Satuan } \\
\text { Pelaksana Diklat } \\
\end{array}$ & $\begin{array}{l}\text { Mengotorisasi Surat Permohonan Kerja } \\
\text { Sama, memberikan Surat Permohonan Kerja } \\
\text { Sama yang telah diotorisasi kepada Satuan } \\
\text { Pelaksana Diklat }\end{array}$ \\
\hline $\begin{array}{l}\text { 3. Mengirimkan contoh } \\
\text { IKS dan Check List } \\
\text { Visitasi }\end{array}$ & $\begin{array}{l}\text { Satuan Pelaksana } \\
\text { Diklat }\end{array}$ & $\begin{array}{l}\text { Menerima Surat } \\
\text { Permohonan Kerja } \\
\text { Sama yang telah } \\
\text { diotorisasi }\end{array}$ & $\begin{array}{l}\text { Mengarsip Surat Permohonan Kerja Sama } \\
\text { yang telah diotorisasi, mengirimkan Check } \\
\text { List Visitasi sebanyak satu rangkap dan } \\
\text { contoh IKS kepada Institusi }\end{array}$ \\
\hline $\begin{array}{l}\text { 4. Menerima IKS dan } \\
\text { Check List Visitasi }\end{array}$ & $\begin{array}{l}\text { Satuan Pelaksana } \\
\text { Diklat }\end{array}$ & $\begin{array}{l}\text { Institusi datang } \\
\text { membawa IKS } \\
\text { sebanyak dua } \\
\text { rangkap beserta } \\
\text { Check List Visitasi } \\
\text { yang telah diisi }\end{array}$ & $\begin{array}{l}\text { menerima IKS sebanyak dua rangkap dan } \\
\text { Check List Visitasi yang telah diisi dari } \\
\text { Institusi, memeriksa IKS, mengotorisasi IKS, } \\
\text { memasukkan data Institusi (ms_institusi) } \\
\text { berdasarkan Check List Visitasi yang telah } \\
\text { diisi oleh Institusi dan IKS, menyerahkan IKS } \\
\text { kepada Kepala Bagian SDM }\end{array}$ \\
\hline 5. Mengotorisasi IKS & Kepala Bagian SDM & $\begin{array}{l}\text { Menerima IKS yang } \\
\text { telah diotorisasi oleh } \\
\text { Satuan Pelaksana }\end{array}$ & $\begin{array}{l}\text { Memeriksa IKS yang telah diotorisasi oleh } \\
\text { Satuan Pelaksana Diklat, mengotorisasi IKS, } \\
\text { memberikan IKS yang telah diotorisasi }\end{array}$ \\
\hline
\end{tabular}




\begin{tabular}{|c|c|c|c|}
\hline Event & $\begin{array}{l}\text { Internal Agent } \\
\text { Assuming } \\
\text { Responsibilities }\end{array}$ & Start When & Activities \\
\hline & & Diklat & kepada Direktur \\
\hline 6. Mengesahkan IKS & Direktur & $\begin{array}{l}\text { Menerima IKS yang } \\
\text { telah diotorisasi oleh } \\
\text { Satuan Pelaksana } \\
\text { Diklat dan Kepala } \\
\text { Bagian SDM }\end{array}$ & $\begin{array}{l}\text { Menandatangani IKS, menyerahkan IKS yang } \\
\text { telah ditandatangani kepada Satuan Pelaksana } \\
\text { Diklat }\end{array}$ \\
\hline $\begin{array}{l}\text { 7. Menerima permohonan } \\
\text { Co - Ass }\end{array}$ & $\begin{array}{l}\text { Satuan Pelaksana } \\
\text { Diklat }\end{array}$ & $\begin{array}{l}\text { Menerima IKS yang } \\
\text { telah disahkan }\end{array}$ & $\begin{array}{l}\text { Mengarsip IKS rangkap satu dan Check List } \\
\text { Visitasi, mengirimkan IKS rangkap dua } \\
\text { kepada Institusi, menerima Surat Permohonan } \\
\text { Co - Ass sebanyak dua rangkap dari Institusi } \\
\text { beserta pas foto dan fotocopy KTP peserta, } \\
\text { memberikan Surat Permohonan Co - Ass } \\
\text { rangkap satu kepada Unit Kerja, mengarsip } \\
\text { Surat Permohonan Co - Ass rangkap dua, } \\
\text { memberitahu Institusi untuk pembuatan Surat } \\
\text { Konfirmasi sebanyak dua rangkap, membuat } \\
\text { Name Tag peserta, memasukkan data calon } \\
\text { peserta ke dalam ms_calon_peserta, membuat } \\
\text { tr_pendaftaran berdasarkan ms_calon_peserta }\end{array}$ \\
\hline $\begin{array}{l}\text { 8. } \\
\text { Penentukan } \\
\text { Pembimbing }\end{array}$ & Unit Kerja & $\begin{array}{l}\text { Menerima Surat } \\
\text { Permohonan Co - Ass } \\
\text { rangkap satu dari } \\
\text { Satuan Pelaksana } \\
\text { Diklat }\end{array}$ & $\begin{array}{l}\text { Membuat Form Penunjukan Pembimbing } \\
\text { (tr_penunjukan_pembimbing), mencetak } \\
\text { Form Penunjukan Pembimbing } \\
\text { (tr_penunjukan_pembimbing) sebanyak satu } \\
\text { rangkap, memberikan Form Penunjukan } \\
\text { Pembimbing (tr_penunjukan_pembimbing) } \\
\text { yang telah dicetak kepada Pembimbing }\end{array}$ \\
\hline $\begin{array}{l}\text { 9. Menerima Surat } \\
\text { Konfirmasi }\end{array}$ & $\begin{array}{l}\text { Satuan Pelaksana } \\
\text { Diklat }\end{array}$ & $\begin{array}{l}\text { Menerima Surat } \\
\text { Konfirmasi sebanyak } \\
\text { dua rangkap dari } \\
\text { peserta Co - Ass }\end{array}$ & $\begin{array}{l}\text { Mengotorisasi Surat Konfirmasi, } \\
\text { memasukkan data peserta yang akan } \\
\text { mengikuti Co - Ass ke dalam ms_peserta, } \\
\text { membuat Form Penerimaan Peserta Co - Ass } \\
\text { (tr_penerimaan), mencetak Form Penerimaan } \\
\text { Peserta Co - Ass (tr_penerimaan) sebanyak } \\
\text { satu rangkap, memberikan Name Tag kepada } \\
\text { peserta, memberikan Surat Konfirmasi } \\
\text { rangkap satu dan Form Penerimaan Peserta } \\
\text { Co - Ass (tr_penerimaan) yang telah dicetak } \\
\text { sebanyak satu rangkap kepada peserta untuk } \\
\text { diberikan kepada Unit Kerja, mengarsip Surat } \\
\text { Konfirmasi rangkap dua, membuat Form } \\
\text { Absensi, memberikan Form Absensi kepada } \\
\text { peserta, menyimpan Daftar Absensi yang } \\
\text { telah diisi oleh peserta }\end{array}$ \\
\hline 10. Memberikan penilaian & Pembimbing & $\begin{array}{l}\text { Kegiatan Co - Ass } \\
\text { dilaksanakan }\end{array}$ & $\begin{array}{l}\text { Memasukkan nilai tes awal ke dalam tr_nilai, } \\
\text { Memasukkan nilai kuis ke dalam tr_nilai, } \\
\text { Memasukkan nilai sikap ke dalam tr_nilai, } \\
\text { Memasukkan nilai ujian tertulis ke dalam } \\
\text { tr_nilai, Memasukkan nilai ujian praktek ke } \\
\text { dalam tr_nilai }\end{array}$ \\
\hline $\begin{array}{l}\text { 11. Membuat Transkrip } \\
\text { Nilai }\end{array}$ & $\begin{array}{l}\text { Satuan Pelaksana } \\
\text { Diklat }\end{array}$ & $\begin{array}{l}\text { Akhir periode } \\
\text { kegiatan } \mathrm{Co}-\text { Ass }\end{array}$ & $\begin{array}{l}\text { Memasukkan Daftar Absensi selama kegiatan } \\
\text { Co - Ass ke dalam tr_absensi, membuat } \\
\text { Transkrip Nilai berdasarkan tr_nilai dan } \\
\text { tr_absensi, mencetak Transkrip Nilai } \\
\text { sebanyak satu rangkap, memberikan } \\
\text { Transkrip Nilai kepada Pembimbing }\end{array}$ \\
\hline $\begin{array}{l}\text { 12. Mengotorisasi } \\
\text { Transkrip Nilai }\end{array}$ & Pembimbing & $\begin{array}{l}\text { Menerima Transkrip } \\
\text { Nilai dari Satuan } \\
\text { Pelaksana Diklat }\end{array}$ & $\begin{array}{l}\text { Memeriksa Transkrip Nilai, mengotorisasi } \\
\text { Transkrip Nilai, menyerahkan Transkrip Nilai } \\
\text { yang telah diotorisasi kepada Satuan } \\
\text { Pelaksana Diklat untuk dikirimkan ke } \\
\text { Institusi }\end{array}$ \\
\hline $\begin{array}{l}\text { 13. Menerima pengajuan } \\
\text { ujian ulang }\end{array}$ & $\begin{array}{l}\text { Satuan Pelaksana } \\
\text { Diklat }\end{array}$ & $\begin{array}{l}\text { Menerima Surat } \\
\text { Pengajuan Ujian }\end{array}$ & $\begin{array}{l}\text { Memberikan Surat Pengajuan Ujian Ulang } \\
\text { rangkap satu kepada Unit Kerja, mengarsip }\end{array}$ \\
\hline
\end{tabular}




\begin{tabular}{|c|c|c|c|}
\hline Event & $\begin{array}{l}\text { Internal Agent } \\
\text { Assuming } \\
\text { Responsibilities }\end{array}$ & Start When & Activities \\
\hline & & $\begin{array}{l}\text { Ulang sebanyak dua } \\
\text { rangkap dari Institusi }\end{array}$ & Surat Pengajuan Ujian Ulang rangkap dua \\
\hline $\begin{array}{l}\text { 14. Mengkonfirmasi } \\
\text { pengajuan ujian ulang }\end{array}$ & Unit Kerja & $\begin{array}{l}\text { Menerima Surat } \\
\text { Pengajuan Ujian } \\
\text { Ulang rangkap satu } \\
\text { dari Satuan Pelaksana } \\
\text { Diklat }\end{array}$ & $\begin{array}{l}\text { Membuat Form Ujian Ulang (tr_ujian_ulang), } \\
\text { mencetak Form Ujian Ulang (tr_ujian_ulang) } \\
\text { sebanyak satu rangkap untuk diberikan } \\
\text { kepada Pembimbing sebagai konfirmasi } \\
\text { adanya pengajuan ujian ulang }\end{array}$ \\
\hline $\begin{array}{l}\text { 15. Memberikan penilaian } \\
\text { ujian ulang }\end{array}$ & Pembimbing & Ujian ulang selesai & $\begin{array}{l}\text { Memasukkan nilai ujian ulang ke dalam } \\
\text { tr_nilai_ujian_ulang }\end{array}$ \\
\hline $\begin{array}{l}\text { 16. Membuat Transkrip } \\
\text { Nilai Ujian Ulang }\end{array}$ & $\begin{array}{l}\text { Satuan Pelaksana } \\
\text { Diklat }\end{array}$ & $\begin{array}{l}\text { Akhir kegiatan ujian } \\
\text { ulang }\end{array}$ & $\begin{array}{l}\text { Membuat Transkrip Nilai Ujian Ulang, } \\
\text { mencetak Transkrip Nilai Ujian Ulang, } \\
\text { memberikan Transkrip Nilai Ujian Ulang } \\
\text { yang telah dicetak kepada Pembimbing }\end{array}$ \\
\hline $\begin{array}{l}\text { 17. Mengotorisasi } \\
\text { Transkrip Nilai Ujian } \\
\text { Ulang }\end{array}$ & Pembimbing & $\begin{array}{l}\text { Menerima Transkrip } \\
\text { Nilai Ujian Ulang }\end{array}$ & $\begin{array}{l}\text { Memeriksa Transkrip Nilai Ujian Ulang, } \\
\text { mengotorisasi Transkrip Nilai Ujian Ulang, } \\
\text { menyerahkan Transkrip Nilai Ujian Ulang } \\
\text { yang telah diotorisasi kepada Satuan } \\
\text { Pelaksana Diklat untuk dikirimkan ke } \\
\text { Institusi }\end{array}$ \\
\hline 18. Membuat Laporan & $\begin{array}{l}\text { Satuan Pelaksana } \\
\text { Diklat }\end{array}$ & $\begin{array}{l}\text { Setelah seluruh } \\
\text { kegiatan Co }- \text { Ass } \\
\text { berakhir (termasuk } \\
\text { kegiatan ujian ulang) }\end{array}$ & $\begin{array}{l}\text { Membuat Laporan Penerimaan Calon Peserta } \\
\text { Co - Ass, membuat Laporan Penerimaan } \\
\text { Peserta Co - Ass, membuat Laporan Peserta } \\
\text { Mengulang, membuat Laporan Absensi, } \\
\text { membuat Laporan Penilaian Peserta, } \\
\text { membuat Laporan Nilai Ujian Ulang, } \\
\text { membuat Laporan Penunjukan Pembimbing, } \\
\text { mencetak semua laporan, memberikan semua } \\
\text { laporan kepada Kepala Bagian SDM, } \\
\text { membuat Laporan Total Peserta, membuat } \\
\text { Laporan Minat Institusi, membuat Laporan } \\
\text { Persentase Kelulusan Peserta, mencetak } \\
\text { semua laporan, memberikan semua laporan } \\
\text { kepada Direktur }\end{array}$ \\
\hline
\end{tabular}

\section{Rancangan yang Diusulkan}

Beberapa rancangan layar Menu ditampilkan pada Gambar 1 - 5. Rancangan class diagram ditampilkan pada Gambar 6. Beberapa rancangan formulir ditampilkan pada Gambar 7 - 12. Beberapa rancangan laporan ditampilkan pada Gambar 13 - 20.

\section{PENUTUP}

Berdasarkan hasil penelitian yang dilakukan pada RSUD mengenai Pengembangan Sistem Informasi Penerimaan dan Penilaian Peserta Co - Ass, dapat disimpulkan bahwa: (1) Dibuatnya laporan-laporan yang dibutuhkan dapat membantu pihak Kepala Bagian SDM dalam menganalisis dan menilai kualitas peserta Co - Ass dari setiap Institusi yang mendaftarkan mahasiswanya untuk mengikuti kegiatan $\mathrm{Co}$ - Ass, mengetahui dengan pasti berapa jumlah peserta $\mathrm{Co}$ - Ass yang mengikuti kegiatan Co - Ass, mengetahui perkembangan peserta Co - Ass selama menjalani kegiatan Co - Ass, mendapatkan informasi mengenai pembimbing yang bertanggung jawab dalam kegiatan Co - Ass dan kualitas dari pembimbing dalam membimbing peserta Co - Ass; (2) penelitian ini menghasilkan suatu rancangan Sistem Informasi Penerimaan dan Penilaian Peserta Co - Ass pada rumah sakit; (3) adanya rancangan Sistem Informasi ini maka dapat mengurangi kemungkinan adanya kehilangan data yang 
dibutuhkan oleh Rumah Sakit khususnya pada bagian Satuan Pelaksana Diklat dan mengurangi kemungkinan adanya kesalahan pencatatan dokumen yang dilakukan oleh bagian Satuan Pelaksana Diklat.

\section{DAFTAR PUSTAKA}

Noerlina. (2008). Evaluasi sistem informasi sumber daya manusia pada bidang usaha jasa. Communication and Information Technology Journal, 2(2).

Rama, Dasartha V \& Jones, Frederick L. (2006). Accounting Information Systems (1 ${ }^{\text {st }} \quad$ edition). Canada: Thomson South-Western.

Sakam \& Surendro. (2007). Pengelolaan tata kelola sistem informasi sumber daya manusia dengan menggunakan cobit framework domain delivery \& support. Jurnal Informatika, Manajemen dan Teknologi, 9(2). 


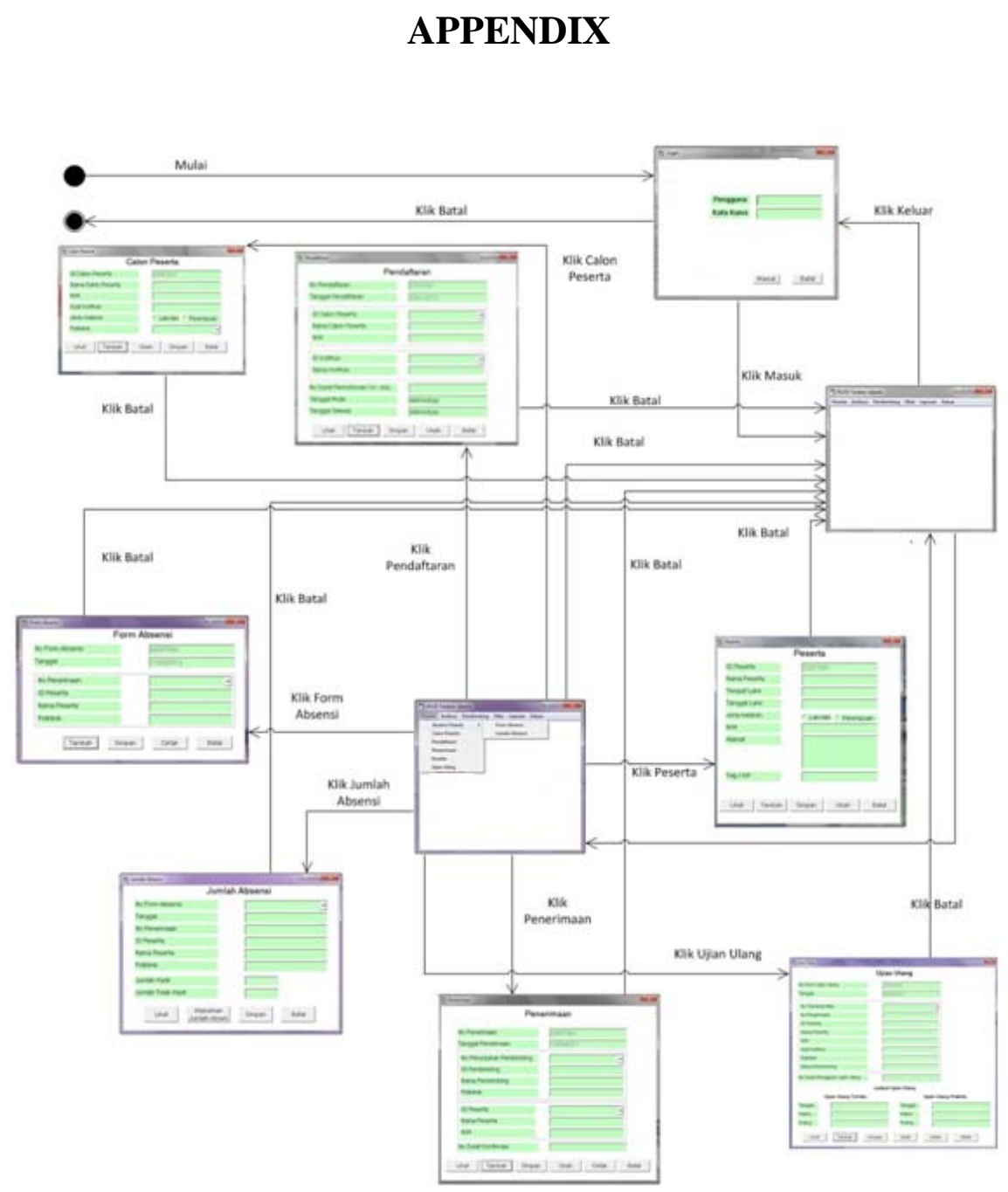

Gambar 1 Navigation Diagram Menu Peserta

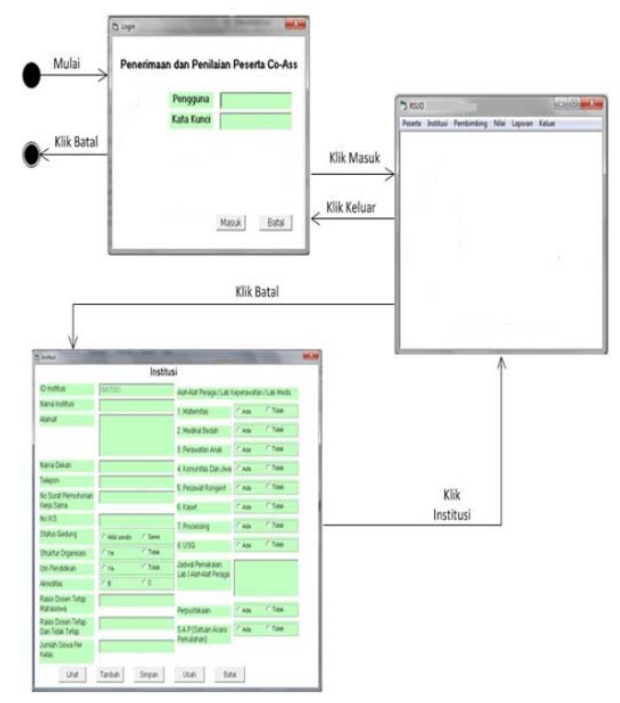

Gambar 2 Navigation Diagram Menu Institusi

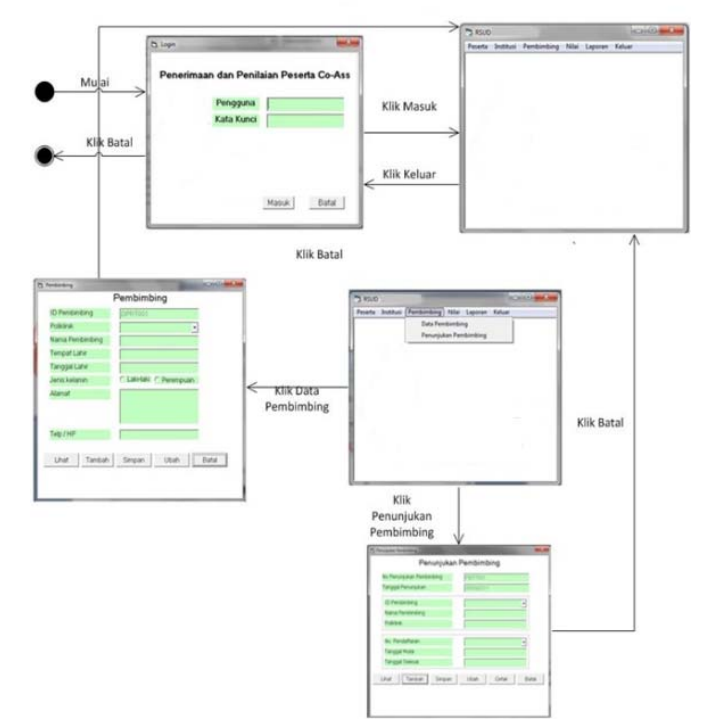

Gambar 3 Navigation Diagram Menu Pembimbing 


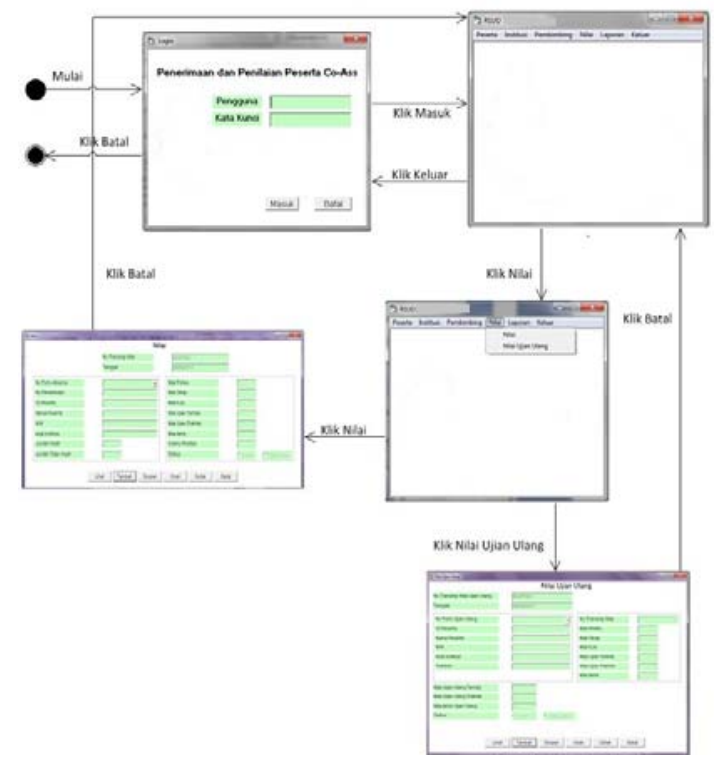

Gambar 4 Navigation Diagram Menu Nilai

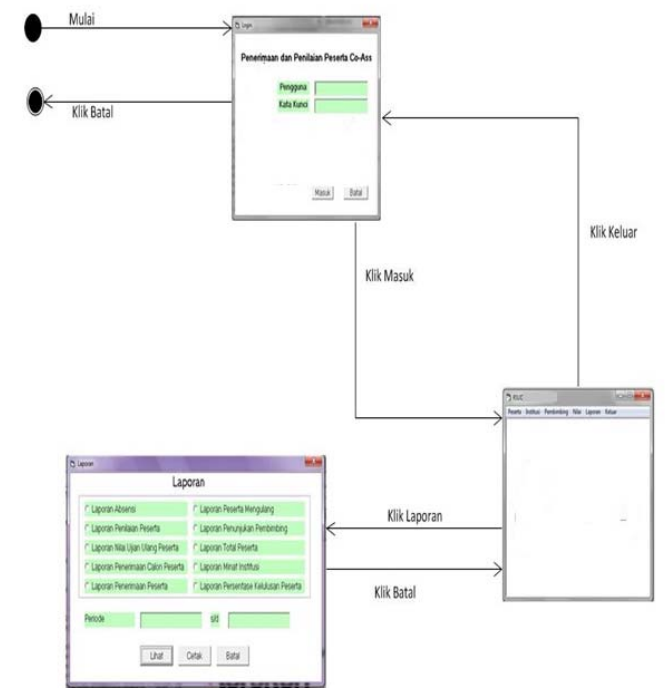

Gambar 5 Navigation Diagram Menu Laporan

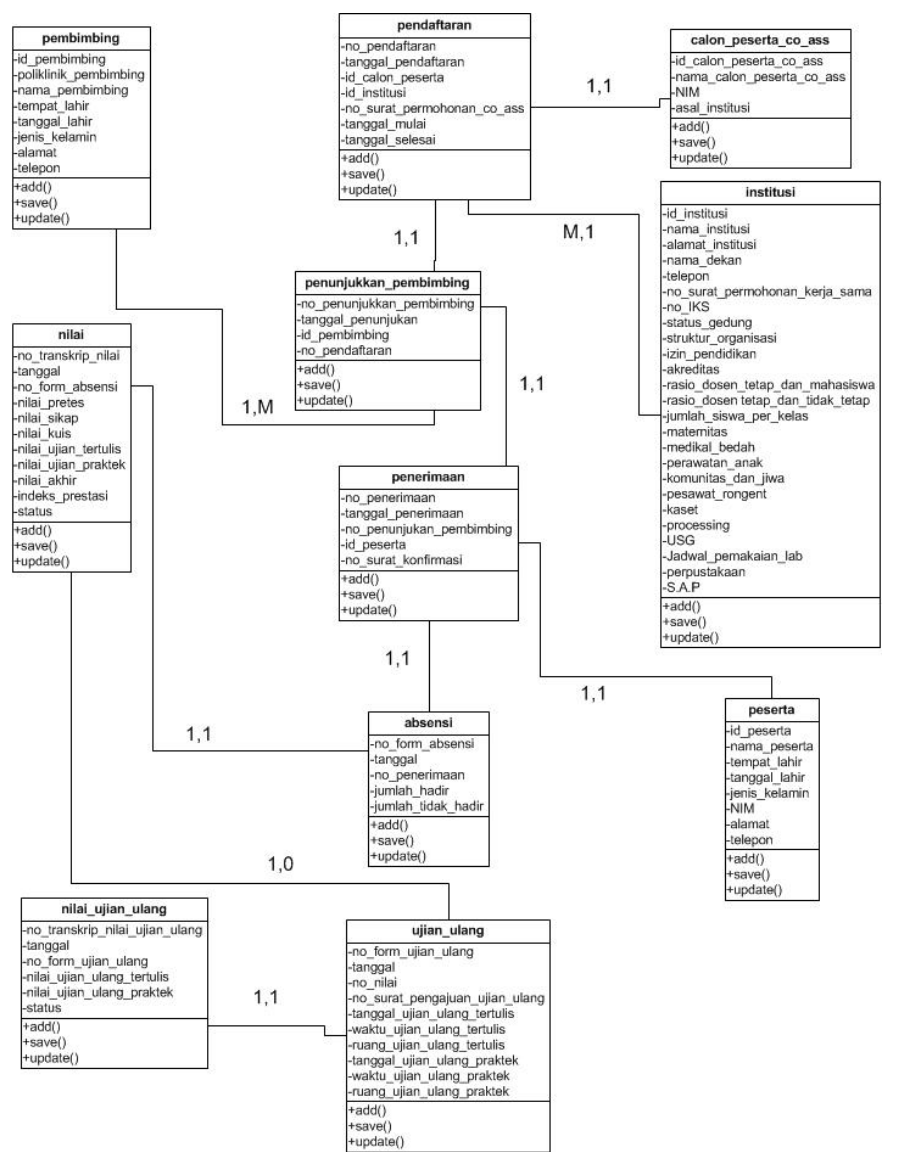

Gambar 6 Class Diagram yang diusulkan pada RSUD 


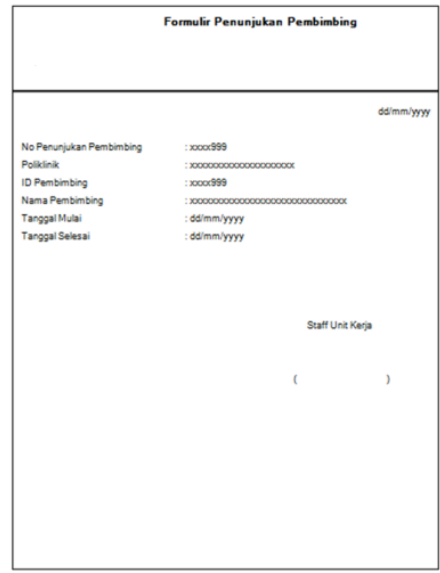

Gambar 7 Rancangan Formulir Penunjukan Pembimbing

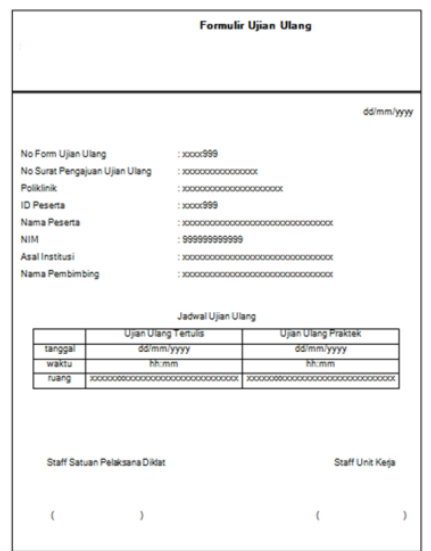

Gambar 9 Rancangan Formulir Ujian Ulang

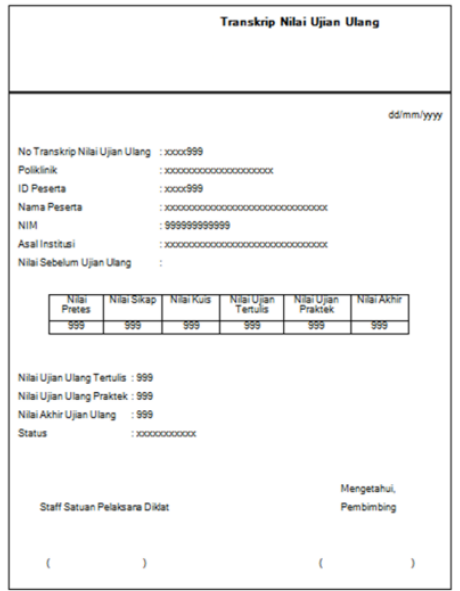

Gambar 11 Rancangan Transkrip Nilai Ujian Ulang

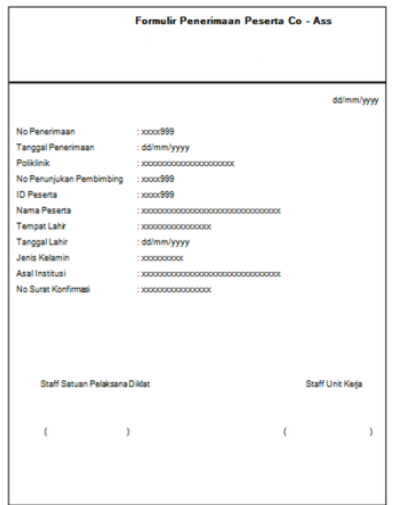

Gambar 8 Rancangan Formulir Penerimaan Peserta Co - Ass

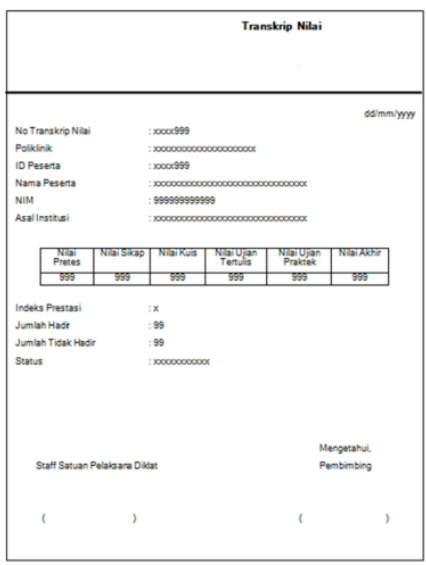

Gambar 10 Rancangan Transkrip Nilai

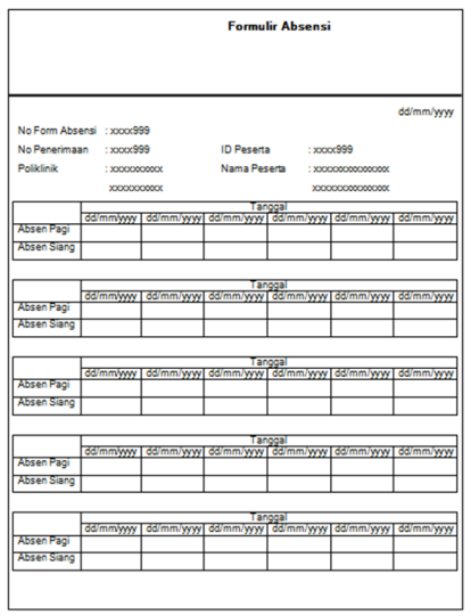

Gambar 12 Rancangan Formulir Absensi 


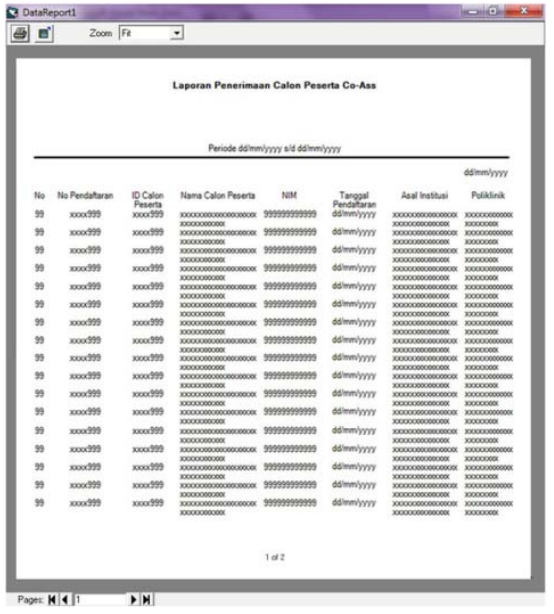

Gambar 13 Rancangan Laporan Penerimaan Calon Peserta Co - Ass

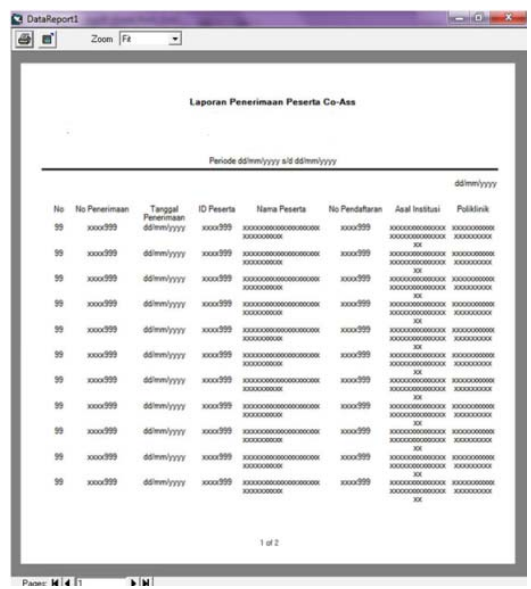

Gambar 15 Rancangan Laporan Penerimaan Peserta Co-Ass

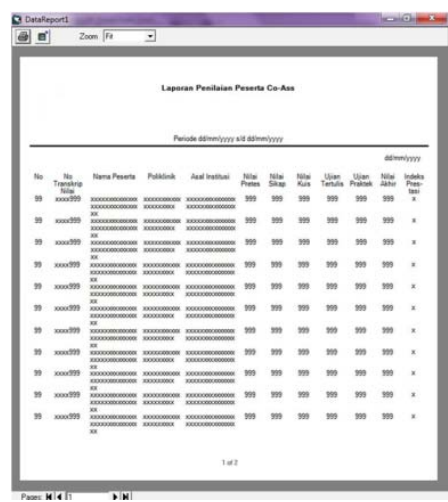

Gambar 17 Rancangan Penilaian Peserta Co - Ass

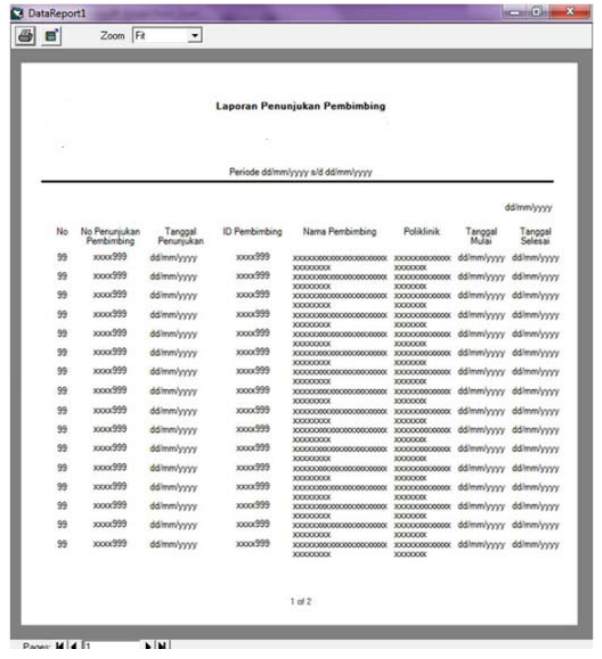

Gambar 14 Rancangan Laporan Penunjukan Pembimbing

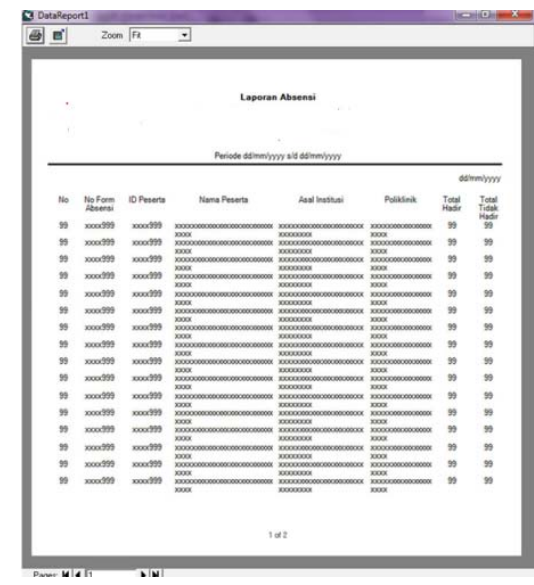

Gambar 16 Rancangan Laporan Absensi

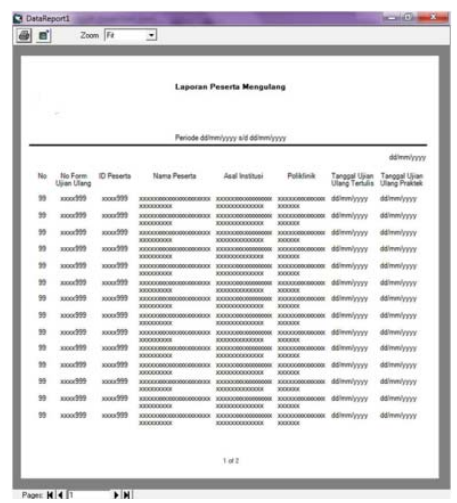

Gambar 18 Rancangan Laporan Peserta Mengulang 


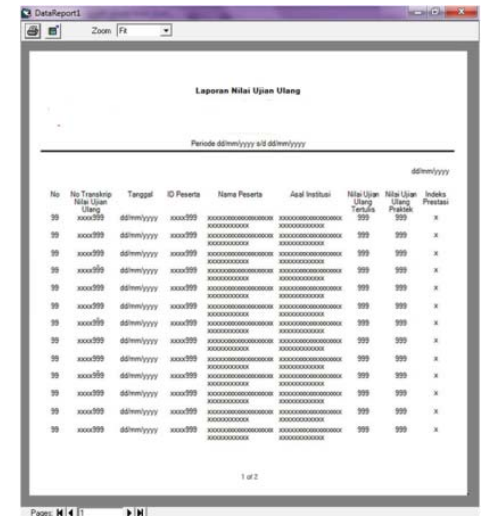

Gambar 19 Rancangan Laporan Nilai Ujian Ulang.

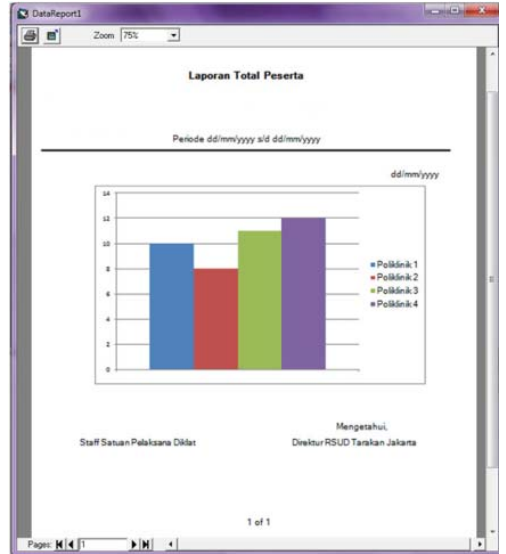

Gambar 20 Rancangan Laporan Total Peserta. 